\title{
Tectonic significance of black pelites and basalts in the St. Croix Terrane, coastal Maine and New Brunswick
}

\author{
L.R. Fyffe \\ New Brunswick Department of Natural Resources and Energy, P.O. Box 6000, Fredericton, New Brunswick \\ E3B $5 \mathrm{HI}$ \\ D.B. Stewart \\ United States Geological Survey, National Center 959, Reston, Virginia 22092 \\ and \\ Allan Ludman \\ Department of Geology, Queens College of the City University of New York, Flushing, \\ New York 11367 \\ Date Received May 9, 1988 \\ Date Accepted March 1, 1989
}

\begin{abstract}
The St. Croix Terrane of coastal Maine and adjacent New Brunswick is characterized by Ordovician carbonaceous pelites in the upper part of the stratigraphic section. These pelites are locally interbedded with mafic volcanic rocks. Metamorphism in the terrane varies from the albite-epidote-homfels facies along the New Brunswick-Maine border to greenschist and lower amphibolite facies in southwesterm Maine.

The mafic volcanic rocks are evolved basalts that have trace-element abundances similar to intraplate tholeiites. Their La/ $\mathrm{Nb}$ ratios of 1.3 to 1.9 and absolute REE concentrations of 30 times chondrite in the more evolved basalts are features common to many continental flood basalts. Enrichment in high field-strength elements relative to MORB distinguishes them from volcanic-arc tholeiites.

Deposition of carbonaceous pelites coincided with the widespread development of oceanic crust in the early Paleozoic. The trace-element and REE patterns of the associated basalts suggest eruption through rifted continental crust marginal to an expanding ocean basin.
\end{abstract}

La présence de pélites riches en carbone dans la partie supérieure de sa section stratigraphique caractérise la Lanière de St. Croix qui se rencontre au littoral du Maine et dans les régions du Nouveau-Brunswick avoisinantes. Ces pélites s'interlitent localement avec des volcanites mafiques. Le métamorphisme de la lanière va du faciès des cornéennes à albite et épidote le long de la frontière entre le Nouveau-Brunswick et le Maine jusqu'au faciès inférieur des amphibolites dans le sud-ouest du Maine.

Les volcanites mafiques sont des basaltes évolués présentant des abondances d'éléments en traces semblables à celles des tholéiites intraplaques. Leurs rapports $\mathrm{La} / \mathrm{Nb}$ de 1.3 à 1.9 , ainsi que leurs concentrations absolues en T.R. égales à 30 fois celles des chondrites au sein des basaltes plus évolués, sont communes à plusieurs nappes d'inondation basaltique continentales. On les distingue des tholéiites d'arc insulaire par leur enrichissement en éléments à intensité de champélevée par rapport aux MORB.

Le dépôt de pélites riches en carbone coïncida avec le développement largement répandu de croûte océanique au début du Paléozoïque. Les spectres de T.R. et d'éléments en traces des basaltes qui leur sont associés suggèrent une éruption à travers une croûte continentale à la dérive en bordure d'un bassin océanique en expansion.

[Traduit par le joumal]

\section{INIRODUCTION}

The northern Appalachians have been divided into a number of fault-bounded terranes that include remnants of oceanic crust, oceanic islands, volcanic arcs, and rifted continental fragments. These terranes formed within or along the margin of an early
Paleozoic ocean and were accreted to the North American continent during the Taconian, Acadian and Alleghenian orogenies (Bird and Dewey, 1970; Williams and Hatcher, 1982).

The Appalachian rocks of southeastern Maine have been divided into three discrete belts (Fig. 1). These are from the southeast to northwest: the Coastal Volcanic Terrane, the St. 

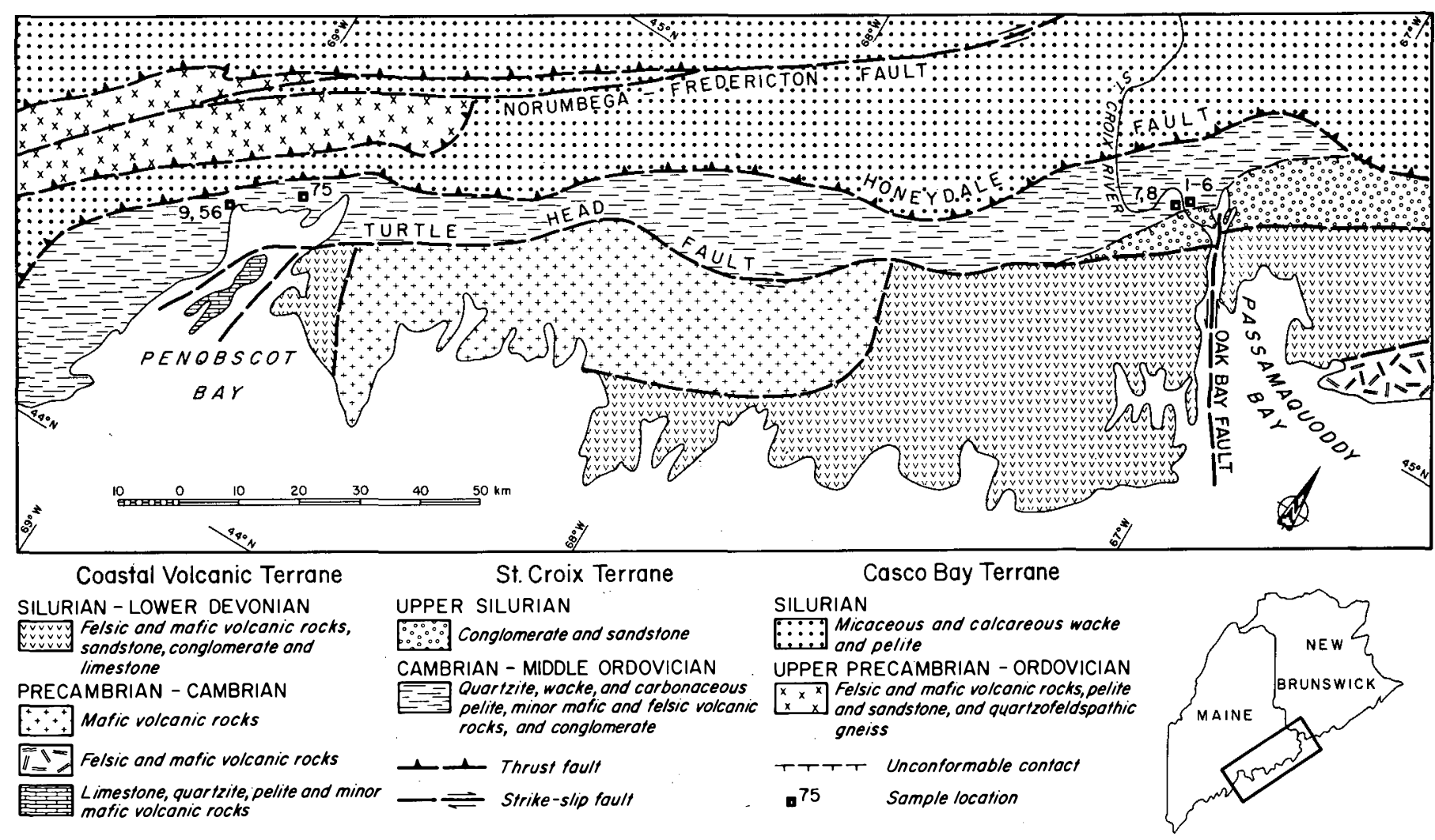

Fig. 1. Geologic map of southeastem Maine and adjacent New Brunswick. Younger plutonic rocks have been omitted. Sources: Stewart and Wones (1974), Bickel (1976), Ruitenberg and Ludman (1978), Osberg et al. (1985).

Croix Terrane, and the Casco Bay Terrane (Stewart and Wones, 1974; Ludman, 1987). Stewart and Wones (1974) correlated the Coastal Volcanic Terrane with the Precambrian Avalonian Terrane of Atlantic Canada, which contains a distinctive European faunal assemblage and may represent a fragment of the EurAfrican craton (Wilson, 1966; Schenk, 1971).

The Casco Bay Terrane is one of several volcanic terranes (including the Miramichi Terrane of central New Brunswick) located between the Coastal Volcanic Terrane and vestiges of an early Paleozoic ocean to the northwest. The St. Croix Terrane is a predominantly sedimentary belt lying between these two volcanic belts. These sedimentary rocks have been interpreted as an early Paleozoic slope sequence deposited off the northwestern margin of Avalon (Schenk, 1971; Rast and Stringer, 1974).

Chemical analyses from volcanic rocks, which are locally interbedded with the sedimentary sequence of the St. Croix Terrane, are reported here in order to provide some constraints on the tectonic environment of the St. Croix Terrane.

\section{STRATIGRAPHY}

Ordovician volcanic rocks within the St. Croix Terrane are exposed in the St. Croix River area on the Canada-U.S.A. border and in the Penobscot Bay area of Maine (Fig. 1). These are mostly mafic in composition but felsic rocks occur locally.

Cambrian-Ordovician rocks on the New Brunswick side of the border are referred to as the Cookson Formation after the excellent section on Cookson Island in Oak Bay at the head of
Passamaquoddy Bay (Ruitenberg, 1967). Recent mapping of lithologic divisions within the same rocks of adjacent Maine required that they be elevated to group status (Ludman, 1987). The newly recognized formations of the Cookson Group are from the base upward: Pocomoonshine Lake Formation - grey to black pelite with minor siltstone and sandstone; Kendall Mountain Formation - quartzite with minor siltstone, pelite, conglomerate and felsic volcanic rocks; Woodland Formation - graded wacke and black pelite; Calais Formation - black carbonaceous pelite with minor siltstone, sandstone and basalt. The Cookson Group is estimated to be about $2,500 \mathrm{~m}$ thick, and the Calais Formation, from which samples were taken for analysis, is in the order of 1,000 m thick (Ludman, 1987).

The mafic rocks in the Calais Formation comprise a pillowed unit and a massive unit. A $100 \mathrm{~m}$ thick, northwest-younging pillow basalt unit is exposed at Todd Point on the New Brunswick side of the St. Croix River (Fig. 2). The massive basalt unit is exposed on the Maine side of the river about $150 \mathrm{~m}$ southeast of the pillow basalt unit. Graded beds in sandstone intercalated with the massive unit indicate a younging direction to the southeast. These top indicators, together with the style of minor folds, suggest that the pillowed and massive basalts occupy approximately the same stratigraphic level on opposite limbs of an anticline overturned to the northwest (Stringer, 1987). The mafic volcanic rocks were thermally metamorphosed to a plagioclaseactinolite-biotite-sphene-iron oxide assemblage during emplacement of nearby Devonian gabbroic plutons. 


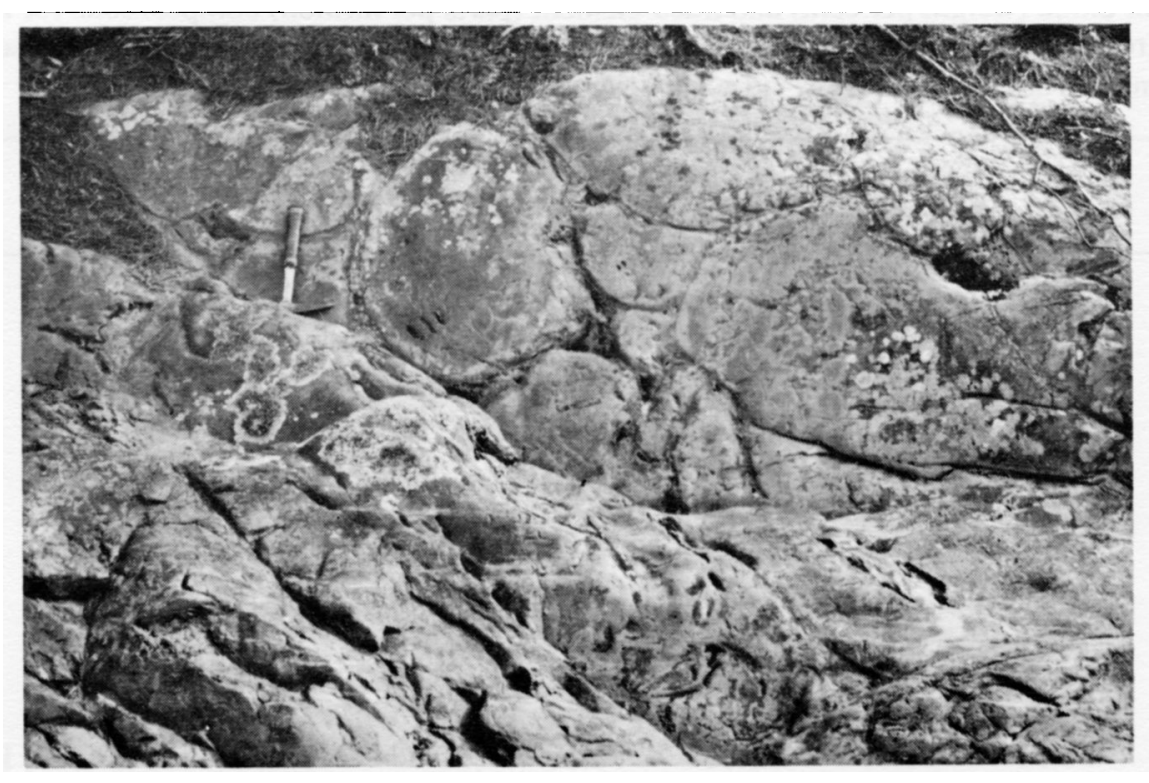

Fig. 2. Northwest-younging pillow basalt at Todd Point on the New Brunswick side of the St. Croix River. Note hammer for scale.

Lithologic correlatives of the Cookson Group in the Penobscot Bay area are quartzite, quartzite-pebble conglomerate and pelite of the Megunticook Formation (150 m of exposed thickness) and conformably overlying carbonaceous pelite, graded quartzose sandstone, and minor amphibolite of the Penobscot Formation (3,150 m thick) (Bickel, 1976; Osberg et al., 1985). Actinolitic hornblende and plagioclase $\left(\mathrm{An}_{30}\right)$, in the amphibolites, together with andalusite and cordierite in the pelitic layers, indicate that regional metamorphism locally reached the lower amphibolite facies in the Penobscot Bay area.

The amphibolites, which locally possess relict pillow-like structures and agglomeratic beds, are included within the Gushee Member ( $500 \mathrm{~m}$ thick) of the upper Penobscot Formation (Bickel, 1976). The Gushee Member appears, therefore, to correspond with the Calais Formation of the Cookson Group, whereas the rest of the Penobscot Formation resembles the Woodland Formation. The Megunticook Formation is lithologically similar to the Kendall Mountain Formation of the Cookson Group, although the latter lacks coarse conglomerate.

The Gushee Member is exposed at the Belfast waterfront where it comprises at least five separate amphibolite layers from 3 to $5 \mathrm{~m}$ thick, each separated by 10 to $20 \mathrm{~m}$ of black pelite and sandstone. Grading in sandstone beds indicates that the sequence is locally younging to the south. The amphibolites typically contain about equal proportions of plagioclase and amphibole (actinolite and actinolitic homblende occur together), with accessory biotite, chlorite, epidote, sphene, Fe-Ti oxides and quartz.

\section{GEOCHEMISTRY}

Their minor representation in the stratigraphic sections together with meagre exposure resulted in only relatively few samples of volcanic rock being collected for study. Eight specimens were analysed from the Calais Formation: samples 1 through 6 (Fig. 1) were collected, respectively, from the top downward within the pillow basalt unit at Todd Point on the New Brunswick side of the St. Croix River; samples 7 and 8 are from the massive basalt unit on the Maine side of the river. Three samples were analyzed from the southem part of the Gushee Member of the Penobscot Formation: samples 9 and 56 were collected at the Belfast waterfront and sample 75 , at the junction of Fletcher Hill and Stockton Springs roads. Samples from the northern portion of the Gushee Member were excluded from this study because of their extensive alteration. The results are presented in Tables 1 and 2; analytical procedures are summarized in Appendix I.

Major-, minor- and trace-element chemistry of volcanic rocks is susceptible to modification by metamorphic fractionation and submarine weathering. However, it has been shown that these secondary processes do not significantly alter the concentrations of some minor and trace elements such as $\mathrm{Ti}, \mathrm{Zr}, \mathrm{Y}, \mathrm{Nb}$ and rare-earth elements (REE's) (Cann, 1970; Elliott, 1973; Field and Elliott, 1974; Herrmann et al., 1974; Winchester and Floyd, 1976, 1977; Floyd and Winchester 1978; Dostal and Capedri, 1979). Although abundances of these "immobile" elements can be influenced by the presence of $\mathrm{CO}_{2}$-rich fluids (Hynes, 1980; Clough and Field, 1980), such alteration may be discerned from the wide range of element concentrations and ratios exhibited by the affected samples (Sun and Nesbitt, 1978; Hellman et al., 1979; Hynes, 1980; Murphy and Hynes, 1986). The suite of eight samples from the Calais Formation and three samples from the southern portion of the Penobscot Formation show no erratic variation in "immobile" element content (Tables 1 and 2) and are, therefore, assumed to reflect primary values for these elements. In contrast, analysed samples from the northern portion of the Penobscot Formation displayed considerable chemical variability (one contained $3.4 \% \mathrm{CO}_{2}$ ) and further sampling would be required before any conclusions could be drawn about their original compositions. 
Table 1. Major-element oxide (weight per cent) and trace-element (parts per million) compositions for mafic rocks of the St. Croix Terrane. Total iron is expressed as $\mathrm{Fe}_{2} \mathrm{O}_{3}$. Sample locations are shown on Figure 1; sample descriptions are given in text and analytical techniques are in Appendix 1. nd = not detected.

\begin{tabular}{|c|c|c|c|c|c|c|c|c|c|c|}
\hline & 1 & 2 & 3 & 4 & 5 & 6 & 7 & 8 & 56 & 75 \\
\hline $\mathrm{SiO}_{2}$ & 47.19 & 46.20 & 48.52 & 47.18 & 47.27 & 48.88 & 47.3 & 49.7 & 48.9 & 48.4 \\
\hline $\mathrm{TiO}_{2}$ & 2.78 & 2.55 & 2.40 & 2.39 & 2.44 & 2.35 & 3.18 & 3.30 & 2.91 & 4.30 \\
\hline $\mathrm{Al}_{2} \mathrm{O}_{3}$ & 17.12 & 15.11 & 15.11 & 14.57 & 15.50 & 14.92 & 15.1 & 16.2 & 14.59 & 13.7 \\
\hline $\mathrm{Fe}_{2} \mathrm{O}_{3} \mathrm{~T}$ & 11.82 & 13.33 & 12.13 & 12.62 & 12.73 & 12.28 & 14.1 & 12.0 & 14.7 & 16.7 \\
\hline $\mathrm{MnO}$ & 0.15 & 0.20 & 0.19 & 0.18 & 0.19 & 0.17 & 0.22 & 0.18 & 0.40 & 0.29 \\
\hline $\mathrm{MgO}$ & 6.46 & 7.47 & 6.74 & 6.82 & 6.47 & 6.27 & 7.10 & 6.39 & 5.97 & 5.58 \\
\hline $\mathrm{CaO}$ & 6.52 & 9.22 & 9.43 & 10.42 & 9.94 & 10.15 & 6.57 & 5.94 & 7.08 & 6.62 \\
\hline $\mathrm{Na}_{2} \mathrm{O}$ & 4.17 & 2.88 & 3.31 & 3.32 & 3.28 & 2.76 & 3.51 & 4.12 & 1.91 & 3.65 \\
\hline $\mathrm{K}_{2} \mathrm{O}$ & 0.25 & 0.53 & 0.21 & 0.13 & 0.14 & 0.36 & 1.27 & 0.82 & 0.29 & 0.44 \\
\hline $\mathrm{P}_{2} \mathrm{O}_{5}$ & 0.28 & 0.26 & 0.24 & 0.25 & 0.24 & 0.24 & 0.46 & 0.47 & 1.03 & 0.48 \\
\hline L.O.I. & 1.8 & 0.8 & 0.6 & 0.8 & 0.4 & 0.5 & 1.0 & 0.4 & 3.4 & 1.1 \\
\hline TOTAL & 98.54 & 98.55 & 98.88 & 98.68 & 98.60 & 98.88 & 99.8 & 99.7 & 101.1 & 101.3 \\
\hline $\mathrm{Mg \#}$ & 53 & 54 & 54 & 53 & 51 & 51 & 51 & 52 & 45 & 41 \\
\hline $\mathrm{Ba}$ & 231 & 300 & 293 & 122 & 116 & 288 & 210 & 350 & 44 & 45 \\
\hline $\mathrm{Rb}$ & 2 & 13 & 3 & nd & nd & 5 & 20 & 30 & 10 & 47 \\
\hline $\mathrm{Sr}$ & 270 & 314 & 352 & 239 & 441 & 263 & 170 & 150 & 160 & 321 \\
\hline Y & 40 & 43 & 38 & 38 & 40 & 36 & 64 & 70 & 69 & 76 \\
\hline $\mathrm{Zr}$ & 197 & 183 & 174 & 174 & 179 & 163 & 270 & 280 & 379 & 317 \\
\hline $\mathrm{Nb}$ & 6 & 6 & 6 & 6 & 5 & 6 & 20 & 30 & 13 & 12 \\
\hline $\mathrm{Ga}$ & 21 & 21 & 21 & 24 & 22 & 21 & - & - & - & - \\
\hline $\mathrm{Zn}$ & 132 & 132 & 124 & 121 & 125 & 121 & - & - & 153 & 148 \\
\hline $\mathrm{Cu}$ & 42 & 21 & 38 & 35 & 57 & 63 & - & - & - & - \\
\hline $\mathrm{Ni}$ & 79 & 90 & 114 & 113 & 115 & 137 & - & - & - & - \\
\hline V & 488 & 429 & 406 & 404 & 421 & 395 & - & - & - & - \\
\hline $\mathrm{Cr}$ & 250 & 240 & 352 & 262 & 253 & 264 & 190 & 200 & 14 & 22 \\
\hline
\end{tabular}

Table 2. Rare-earth-element compositions (parts per million) for mafic rocks of the St. Croix Terrane. Analytical techniques are in Appendix 1.

\begin{tabular}{lccccccc}
\hline & 2 & 5 & 7 & 8 & 9 & 56 & 75 \\
\hline $\mathrm{La}$ & 8.0 & 7.5 & 11.5 & 11.2 & 11.9 & 25.0 & 15.4 \\
$\mathrm{Ce}$ & 23.4 & 21.5 & 33.1 & 33.0 & 28.3 & 62 & 42 \\
$\mathrm{Pr}$ & 3.9 & 3.7 & 5.6 & 5.6 & 4.7 & - & - \\
$\mathrm{Nd}$ & 19.3 & 19.6 & 30.5 & 31.2 & 24.1 & 41 & 30.7 \\
$\mathrm{Sm}$ & 6.3 & 5.5 & 9.1 & 9.6 & 6.4 & 11.1 & 9.2 \\
$\mathrm{Eu}$ & 1.99 & 2.19 & 2.84 & 2.78 & 2.24 & 3.8 & 2.92 \\
$\mathrm{Gd}$ & 7.3 & 7.2 & 11.6 & 12.9 & 7.8 & 12.2 & 9.6 \\
$\mathrm{~Tb}$ & 1.3 & 1.2 & 1.9 & 2.1 & 1.4 & 2.22 & 2.13 \\
$\mathrm{Dy}$ & 7.9 & 7.8 & 12.1 & 13.0 & 8.4 & - & - \\
$\mathrm{Ho}$ & 1.63 & 1.58 & 2.52 & 2.89 & 1.79 & - & - \\
$\mathrm{Er}$ & 4.4 & 4.4 & 7.4 & 7.7 & 4.8 & - & - \\
$\mathrm{Tm}$ & 0.6 & 0.7 & 0.9 & 1.0 & 0.7 & 0.93 & 0.98 \\
$\mathrm{Yb}$ & 3.6 & 3.9 & 6.2 & 6.5 & 4.0 & 6.64 & 7.31 \\
$\mathrm{Lu}$ & 0.54 & 0.58 & 1.06 & 1.02 & 0.60 & 1.00 & 1.09 \\
& & & & & & & \\
\hline
\end{tabular}


The analysed samples from the St. Croix Terrane contain 47.8 to $50.7 \% \mathrm{SiO}_{2}$ (recalculated to $100 \%$ on a volatile-free basis) and are, therefore, basaltic in composition (Table 1). Most are silica-saturated, i.e., hypersthene-normative (CIPW norms were calculated using an $\mathrm{FeO} / \mathrm{FeO}_{\mathrm{T}}$ ratio of 0.85 ), but sample 56 is oversaturated (quartz-normative). All samples have immobile trace-element $\mathrm{Nb} / \mathrm{Y}$ ratios of less than 0.43 and, therefore, fall well into the subalkalic field (Winchester and Floyd, 1977). Sample 56 would, however, be classified as alkalic on the basis of its $\mathrm{Zr} / \mathrm{P}_{2} \mathrm{O}_{5}$ ratio and $\mathrm{TiO}_{2}$ content (Winchester and Floyd, 1976). A plot of total iron against $\mathrm{Mg}$ ' values $\left(\mathrm{Mg}^{\prime}=100 \mathrm{MgO} /\right.$ $\mathrm{MgO}+0.9 \mathrm{FeO}_{\mathrm{T}}$ ) (molar proportions) suggests that the basalts are tholeiitic rather than calc-alkalic (Fig. 3) but Fe/Mg ratios may have been affected by alteration (see below). However, no andesitic compositions, characteristic of calc-alkalic suites, were found among the samples, in support of tholeiitic affinity.

The pillow basalts (Samples 1 to 6) of the Calais Formation have $\mathrm{Mg}$ ' values ranging from 51 to 54 (average 53). These values (Table 1, Fig. 3) may not be primary as two previously published analyses of the same basalt on the Maine side of the St. Croix River show a variation of $\mathrm{Mg}$ ' from 64 to 55 between the core and rim of pillows due to submarine alteration (Ludman, 1987). However, immobile-element ratios are not expected to vary significantly across pillows (Floyd and Winchester, 1978). The massive basalts (Samples 7 and 8 ) of the Calais Formation possess an average $\mathrm{Mg}$ ' value of 51 . The amphibolites of the Penobscot Formation (Samples 56 and 75), with an average Mg' value of 43 , would appear to be more highly evolved (Frey et al., 1978). The low $\mathrm{Cr}$ concentrations of the amphibolites (average $18 \mathrm{ppm}$ ) suggest that they have undergone a high degree of fractionation consistent with their low Mg' values.

Higher concentrations of incompatible high-field-strength trace elements such as $\mathrm{Y}, \mathrm{Nb}$ and $\mathrm{Zr}$ indicate a more evolved character for the massive basalt compared to the pillow basalt of the Calais Formation (Table 1, Fig. 4). Correspondingly, REE contents in the massive basalt (Samples 7 and 8) are two to three times that of the pillow basalt (Samples 2 and 5) (Table 2, Fig. 5). A similar variation in REE abundances is present in the amphibolite unit of the Penobscot Formation (sample 9 vs. samples 56 and 75).

Geochemical patterns of lithophile elements normalized to average mid-oceanic ridge basalt (MORB) composition can be used to constrain the tectonic settings in which basaltic magma has been generated (Pearce, 1982). Mafic rocks of the St. Croix Terrane exhibit enrichment in the incompatible elements $\mathrm{Sr}$ through Y (Fig. 4), similar to that observed in intraplate tholeiitic basalts. This similarity is supported by the ratios of high-fieldstrength elements Nb:Zr:Y (Fig. 6). Overlap of massive basalt samples into the E-MORB field is probably due to inaccuracy in the $\mathrm{Nb}$ analytical technique used for samples 7 and 8 (Appendix I).

Continental as opposed to oceanic intraplate tholeiites generally contain higher concentrations of large, low-valence cations (Sr, K, Rb, Ba) (Thompson et al., 1983, 1984). When compared to oceanic tholeiites of the Hawaiian Islands (Pearce, 1982) and Mesozoic continental tholeiites of southern Africa (Cox, 1983) and the Atlantic margins (Dupuy and Dostal, 1984),

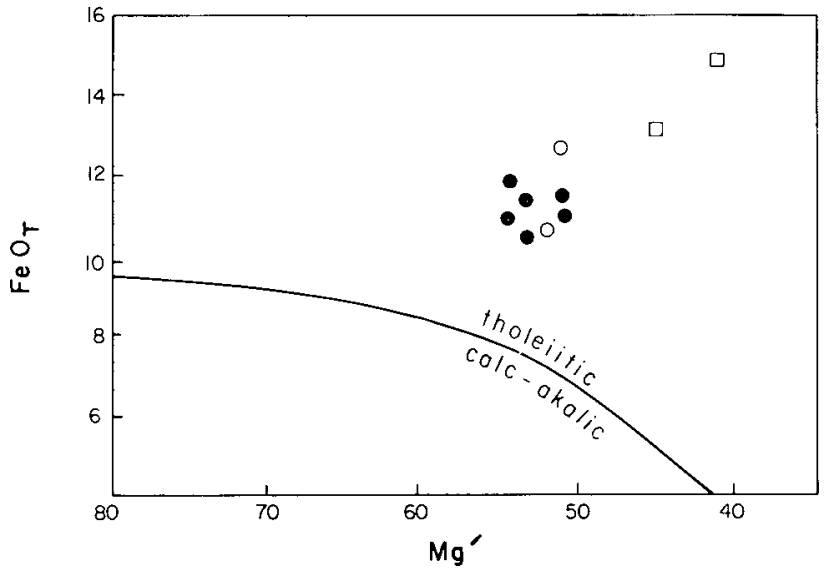

Fig. 3. Plot of magnesium number $\left(\mathrm{Mg}^{\prime}\right)$ against total iron $\left(\mathrm{FeO}_{\uparrow}\right)$. Boundary between tholeiitic and calc-alkalic fields from data of Miyashiro (1974). Legend: open squares $=$ amphibolite of Penobscot Formation (samples 56 and 75); closed circles = pillow basalt of Calais Formation (samples 1 to 6); open circles = massive basalt of Calais Formation (samples 7 and 8 ).

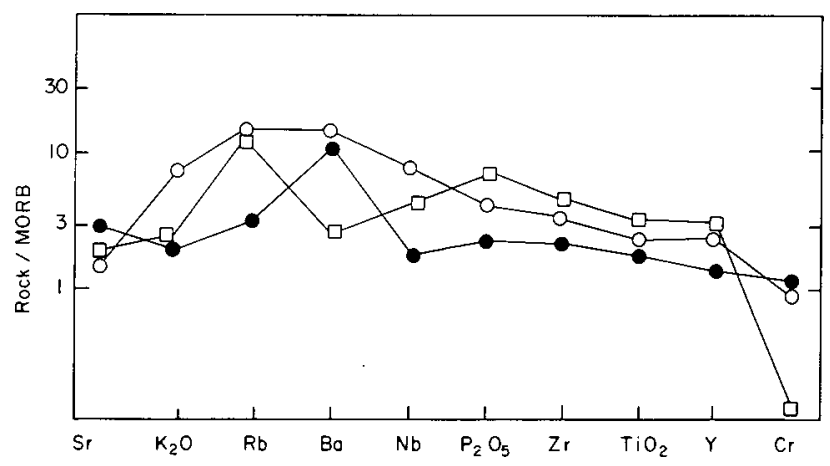

Fig. 4. MORB-normalized incompatible-compatible element patterns for average mafic rocks of the $\mathrm{St}$. Croix Terrane. Normalizing values are from Pearce (1982). Legend as in Figure 3.

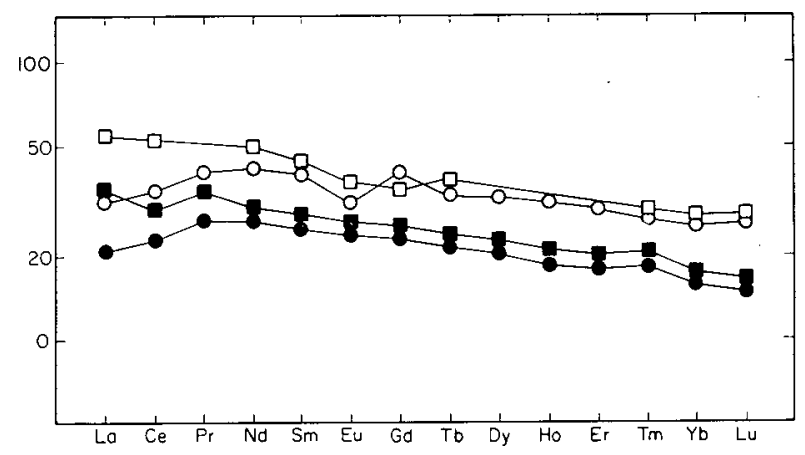

Fig. 5. Chondrite-normalized rare-earth-element patterns for average mafic rocks of the St. Croix Terrane. Normalizing values are from Taylor and McLennan (1985). Legend: closed squares = sample 9 and open sqares $=$ samples 56 and 75 from amphibolites of Penobscot Formation; closed circles $=$ samples 2 and 5 and open circles $=$ samples 7 and 8 from basalts of Calais Formation. 


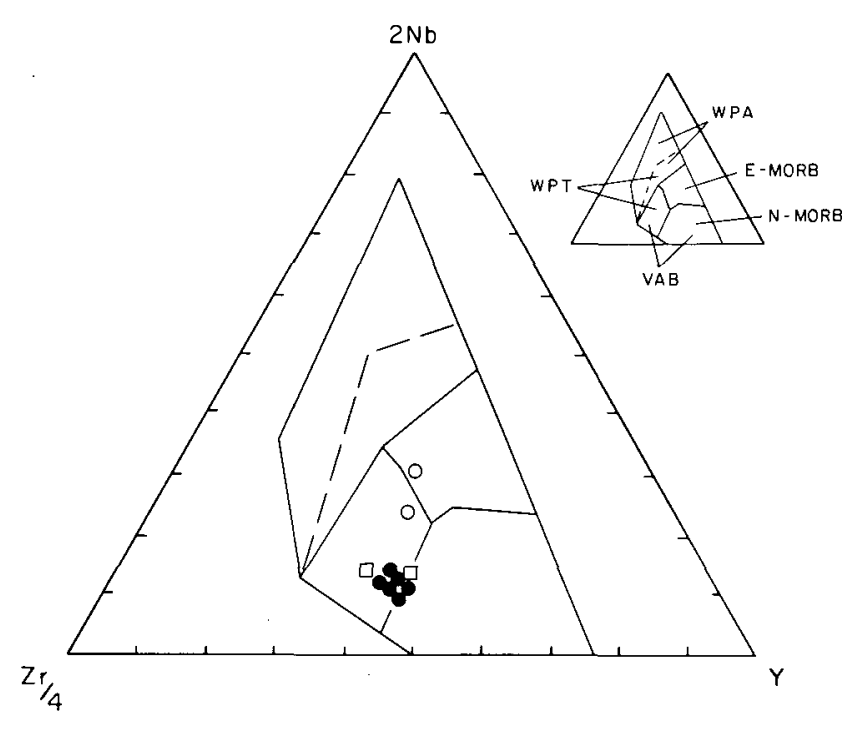

Fig. 6. Nb-Zr-Y discrimination diagram after Meschede (1986). NMORB = normal mid-oceanic-ridge basalt; E-MORB = enriched midoccanic-ridge basalt; $\mathrm{VAB}=$ volcanic-arc basalt; WPT = within-plate tholeiitic basalt; WPA = within-plate alkalic basalt. Legend as in Figure 3.

trace-element patterns of the less evolved (pillowed) basalts from the St. Croix Formation strongly resemble those of the latter two groups, i.e., they contain high $\mathrm{Ba}$ to $\mathrm{Nb}$ ratios (Fig. 4). Although this is suggestive of an intracontinental origin for these volcanic rocks, such a conclusion must be viewed with caution given the mobility of $\mathrm{K}_{2} \mathrm{O}, \mathrm{Rb}, \mathrm{Sr}$ and $\mathrm{Ba}$ during alteration processes (Cann, 1970). This mobility is evident from the irregularity of the patterns on the left compared to the right side of Figure 4.

REE abundances also provide constraints on tectonic setting of volcanic rocks. In contrast to normal MORB, intraplate tholeiitic basalts are enriched in light REE (LREE) relative to heavy REE (HREE) with $\mathrm{La} / \mathrm{Yb}$ (chondrite-normalized) ratios typically ranging from 2 to 10 (Basaltic Volcanism Study Project, 1981). Also, LREE tend to be less strongly enriched relative to middle REE in oceanic compared to continental intraplate environments. For example, tholeiitic basalts of the Hawaiian Islands and the Triassic of continental Nova Scotia have normalized La/ Sm ratios of 1.4 (Basaltic Volcanic Study Group, 1981) and 2.1 (Dostal and Dupuy, 1984), respectively.

The volcanic rocks of the St. Croix Terrane are all enriched in LREE relative to HREE so that they are distinct from normal MORB (Table 2, Fig. 5). Amphibolites from the Penobscot Formation are more highly enriched in LREE than basalts from the Calais Formation (normalized $\mathrm{La} / \mathrm{Yb}$ ratios range from 1.42.7 and 1.2-1.5, respectively). Normalized La/Sm ratios from the Calais (0.73-0.85) and Penobscot formations (1.05-1.41) are similar to those of normal MORB and oceanic island tholeiites, respectively. However, $\mathrm{La} / \mathrm{Nb}$ ratios, which do not exceed 1.25 in oceanic basalts (Thompson et al., 1984), range from 1.3 to 1.5 in the pillow basalt of the Calais Formation, and from 1.3 to 1.9 in the amphibolite of the Penobscot Formation. Furthermore, HREE abundances of 30 times chondrite for the more evolved volcanic rocks of the St. Croix Terrane are far in excess of the 6 to 15 times chondrite found in oceanic tholeiites (Basaltic Volcanism Study Project, 1981).

\section{DISCUSSIONAND CONCLUSIONS}

A distinctive Atlantic fauna within the Avalonian Terrane of southern New Brunswick demonstrates that in the Early Cambrian, an oceanic tract had sufficient width to present a barrier to faunal exchange with the North American craton. Remnants of this oceanic crust, preserved within the northeastern Appalachians, range in age from Late Cambrian to Early Ordovician (Dunning and Krogh, 1985; Boone and Boudette, 1989). Subsequent compressional events in this region apparently record the accretion of various terranes to the North American craton during closure of the oceanic basin(s) (Ludman, 1981, 1986; Zen, 1983; Fyffe and Fricker, 1987; van Staal, 1987; van der Pluijm and van Staal, 1988; Boone and Boudette, 1989).

Widespread deposition of black carbonaceous pelite in Maine and New Brunswick coincided with the extensive development of early Paleozoic oceanic crust. To the northeast of the Casco Bay Terrane, late Tremadocian to Arenigian (Early Ordovician) black pelites, succeeding a coarser sandstone sequence, are known throughout the Miramichi Terrane of central New Brunswick (Fyffe et al., 1983). The pelites immediately underlie a thick, bimodal Middle Ordovician (Llanvirnian to early Caradocian) volcanic sequence that_was generated during extension of continental crust (van Staal, 1987). Rift basins in this area were locally floored by oceanic crust, i.e., the Fournier ophiolite (Rast and Stringer, 1980) of the Elmtree Terrane in northeastern New Brunswick. Black pelites of Tremadocian age also were deposited within the Avalonian Terrane where they form the upper Saint John Group (Ludman, 1987). These pelites overlie platformal sedimentary rocks and interbedded continental volcanic rocks of the lower Saint John Group (Greenough et al., 1985). An extensional regime thus appears to have persisted within the Avalonian Terrane from the Cambrian to Early Ordovician.

The depositional interval of black pelite (and interbedded volcanic rocks) in the St. Croix Terrane is, at least in part, coeval with that of the flanking Miramichi and Avalonian terranes. Graptolites from Cookson Island, located about $7 \mathrm{~km}$ along strike to the east of the sampled volcanic rocks on the St. Croix River, are Tremadocian in age (Cumming, 1967; Ruitenberg and Ludman, 1978).

The geochemistry of the St. Croix volcanic rocks supports the regional stratigraphic evidence that during the early Paleozoic, an extensional environment existed on the southeastern side of an expanding ocean basin. These basalts are enriched in highfield-strength elements relative to normal MORB so they are unlike most volcanic-arc tholeiites (Pearce, 1982). Therefore, it is very unlikely that a consuming plate margin existed between the St. Croix and any of its opposed terranes. The highly evolved nature of some of the basalts (HREE are 30 times chondritic abundances) and $\mathrm{La} / \mathrm{Nb}$ ratios greater than 1.25 suggest a continental setting as does the strongly LREE-enriched pattern of the basalts form the Penobscot Formation. The basalts of the Calais Formation exhibit a marked depletion of light, relative to middle REE but such patterns are known from passive continental margins (O'Nions and Clarke, 1972; Komprobst et al., 1988).

On the basis of stratigraphic and geochemical data, the St. Croix Terrane is interpreted to be underlain by continental crust that underwent rifting during generation of an early Paleozoic 
oceanic basin. Although the terrane appears to have originated somewhere along the southeastern margin of this ocean, its specific source region is unknown as considerable strike-slip motion may have taken place along its bounding faults.

\section{ACKNOWLEDGEMENTS}

We wish to thank Peter Stringer for sharing his detailed stratigraphic and structural knowledge of the Canadian St. Croix River section. We also thank Rao Irrinki for computer manipulation of the chemical data, Terry Leonard for drafting the figures, Karen Gallagher for preparing the tables and Diane Blair for word processing. Malcolm Hill and an anonymous reviewer provided valuable critiques of the original manuscript.

BASALTIC VOLCANISM STUDY PROJECT. 1981. Basaltic volcanism on the terrestrial planets. Pergamon Press, Inc., New York, $1286 \mathrm{p}$.

BICKEL, C.E. 1976. Stratigraphy of the Belfast quadrangle, Maine. In Contributions to the stratigraphy of New England. Edited by L.R. Page. Geological Society of America, Memoir 148, pp. 97-128.

BIRD, J.M. and DEWEY, J.F. 1970. Lithosphere plate-continental margin tectonics and the evolution of the Appalachian orogen. Geological Society' of America Bulletin, 81, pp. 1031-1059.

BOONE, G.M. and BOUDETTE, E.L. 1989. Accretion of the Boundary Mountains terrane within the northem Appalachian orthotectonic zone. Geological Society of America, Special Paper 228, pp. $17-42$.

CANN, J.R. 1970. Rb, Sr, Y, Zr and $\mathrm{Nb}$ in some ocean floor basaltic rocks. Earth and Planetary Science Letters, 10, pp. 7-11.

CLOUGH, P.W.L. and FIELD, D. 1980. Chemical variation in metabasites from a Proterozoic amphibolite-granulite transition zone, south Norway. Contributions to Mineralogy and Petrology, 73, pp. 277-286.

COX, K.G. 1983. The Karoo province of southem Africa: origin of trace element enrichment patterns. In Continental Basalts and Mantle Xenoliths. Edited by C.J. Hawkesworth and M.J. Norry. Shiva Publishing Limited, pp. 139-157.

CUMMING, L.M. 1967. Geology of the Passamaquoddy Bay region, Charlotte County, New Brunswick. Geological Survey of Canada. Paper 65-29, $36 \mathrm{p}$.

DOSTAL J. and CAPEDRI, S. 1979. Rare-earth elements in high-grade metamorphic rock from the western Alps. Lithos, 12, pp. 41-49.

DOSTAL, J. and DUPUY, C. 1984. Geochemistry of the North Mountain basalts (Nova Scotia, Canada). Chemical Geology, 45, pp. 245-261.

DUNNING, G.R. and KROUGH, T.E. 1985. Geochonology of ophiolites of the Newfoundland Appalachians. Canadian Joumal of Earth Sciences, 22, pp. 1659-1670.

DUPUY, C. and DOSTAL, J. 1984. Trace element geochemistry of some continental tholeiites. Earth and Planetary Science Letters, 67, pp. 61-69.

ELLIOTT, R.B. 1973. The chemistry of gabbro/amphibiolite transitions in south Norway. Contributory to Mineralogy and Petrology, 38, pp. 71-79.

FIELD, D. and ELLIOTT, R.B. 1974. The chemistry of gabbro/ amphibolite transitions in south Norway II: trace elements. Contributions to Mineralogy and Petrology, 47, pp. 63-76.

FLOYD, P.A. and WINCHESTER, J.A. 1978. Identification and discrimination of altered and metamorphosed volcanic rocks using immobile elements. Chemical Geology, 21, pp. 291-306.
FREY, F.A., GREEN, D.H., and ROY, S.D. 1978. Integrated models of basalt petrogenesis: a study of quartz tholeiites to olivine melilitites from south-eastern Australia utilizing geochemical and experimental petrological data. Journal of Petrology, 19, pp. 463 513.

FYFFE, L.R. and FRICKER, A. 1987. Tectonostratigraphic terrane analysis of New Brunswick. Maritime Sediments and Atlantic Geology, 23, pp. 113-122.

FYFFE, L.R., FORBES, W.H., and RIVA, J. 1983. Graptolites from the Benton area of west-central New Brunswick and their regional significance. Maritime Sediments and Atlantic Geology, 19, pp. 117-125.

GREENOUGH, J.D., MCCUTCHEON, S.R., and PAPEZIK, V.S. 1985. Petrology and geochemistry of Cambrian volcanic rocks from the Avalon Zone in New Brunswick. Canadian Journal of Earth Sciences, 22, pp. 881-892.

HELLMANN, P.L., SMITH, R.E., and HENDERSON, P. 1979. The mobility of rare earth elements: evidence and implications from selected terrains affected by burial metamorphism. Contributions to Mineralogy and Petrology, 71, pp. 23-44.

HERRMANN, A.G., POTTS, M.J., and KNARE, D. 1974. Geochemistry of the rare earth elements in spilites from the oceanic and continental crust. Contributions to Mineralogy and Petrology, 44. pp. 1:-16.

HYNES, A. 1980. Carbonatization and mobility of Ti, Y, and $\mathrm{Zr}$ in Ascot Formation metabasalts, SE Quebec. Contributions to Mineralogy and Petrology, 75, pp. 79-87.

KORNPROBST, J., VIDAL, P., and MALOD, J. 1988. Les basaltes de la Marge de Galice (NO de la Péninsule Ibérique): hétérogénéité des spectres de terres rares à la transition continent/océan. Données géochimiques préliminaires. Comptes Rendus de l'Académie des Sciences de Paris, 306, Série II, pp. 1359-1364.

LUDMAN, A. 1981. Significance of transcurrent faulting in eastern Maine and location of the suture between Avalonia and North America. American Joumal of Science, 281, pp. 463-483.

1986. Timing of terrane accretion in eastern and east-central Maine. Geology, 14, pp. 411-414.

1987. Pre-Silurian stratigraphy and tectonic significance of the St. Croix belth southeastem Maine. Canadian Journal of Earth Sciences, 24, pp. 2459-2469.

MESCHEDE, M. 1986. A method of discriminating between different types of mid-ocean ridge basalts and continental tholeiites with the Nb-Zr-Y diagram. Chemical Geology, 56, pp. 207-218.

MIYASHIRO, A.F. 1974. Volcanic rock series in island arcs and active continental margins. American Journal of Science, 274, pp. 321 355.

MURPHY, J.B. and HYNES, A.J. 1986. Contrasting secondary mobility of $\mathrm{Ti}, \mathrm{P}, \mathrm{Zr}, \mathrm{Nb}$, and $\mathrm{Y}$ in two metabasaltic suites in the Appalachians. Canadian Journal of Earth Sciences, 23, pp. 1138 1144.

O'NIONS, R.K. and CLARKE, D.B. 1972. Comparison trace element geochemistry of Tertiary basalts from Baffin Bay. Earth and Planetary Science Letters, 15, pp. 436-446.

OSBERG, P.H., HUSSEY, A.M., II., and BOONE. G.M. 1985. Bedrock geologic map of Maine. Maine Geological Survey, Augusta, Maine, U.S.A.

PEARCE, J.A. 1982. Trace isotopic characteristics of lava from destructive plate boundaries. In Andesites: orogenic andesites and related rocks. Edited by R.S. Thorpe. John Wiley \& Sons, New York, pp. 525-548.

RAST, N. and STRINGER, P. 1974. Recent advances and the interpretation of geological structure of New Brunswick. Geos- 
cience Canada, 1, pp. 15-25.

. 1980. A geotraverse across a deformed Ordovician ophiolite and its Silurian cover, northem New Brunswick, Canada. Tectonophysics, 69, pp. 221-245.

RUITENBERG, A.A. 1967. Stratigraphy, structure and metallization, Piskahegan-Rolling Dam area, northem Appalachians, New Brunswick, Canada. Leidse Geologische Mededelingen, 40, pp. 79120.

RUITENBERG, A.A. and LUDMAN, A. 1978. Stratigraphy and tectonic setting of Early Paleozoic sedimentary rocks of the Wirr alBig Lake area, southwestem New Brunswick and southeastem Maine. Canadian Journal of Earth Sciences, 15, pp. 22-32.

SCHENCK, P.E. 1971. Southeastern Atlantic Canada, northwestem Africa and continental drift. Canadian Journal of Earth Sciences, 8, pp. 1218-1251.

STEWART, D.B. and WONES, D.R. 1974. Bedrock geology of northem Penobscot Bay area. In New England Intercollegiate Geologic Conference Guidebook for field trips in east-central and north-central Maine. Edited by P.H. Osberg, University of Maine, Orono, Maine, pp. 223-239.

STRINGER, P. 1987. Stratigraphy and stnucture of the Cookson Formation. University of New Brunswick, Fredericton, New Brunswick, Unpublished Report 28 p.

SUN, S.S. and NESBITT, R.W. 1978. Petrogenesis of Archaean ultrabasic and basic volcanics: evidence from rare earth elements. Contributions to Mineralogy and Petrology, 65, pp. 301-325.

TAYLOR, S.R. and MCLENNAN, S.M. 1985. The continental crust: its composition and evolution. Blackwell Scientific Publications, London, p. 298.

THOMPSON, R.N., MORRISON, M.A., DICKIN, A.P., and HENDRY, G.L. 1983. Continental flood basalts - arachnids rule O.K.? In Continental Basalts and Mantle Xenoliths. Edited by C.J. Hawkesworth and M.J. Norry. Shiva Publishing Limited, pp. 139157.

THOMPSON, R.N., MORRISON, M.A., HENDRY, G.L., and PARRY, S.J. 1984. An assessment of the relative roles of crust and mantle in magma genesis: an elemental approach. Royal Society of London, Philosophical Transactions, A310, pp. 549-590.

VAN DER PLUIJM, B.S. and VAN STAAL, C.R. 1988. Characteristics and evaluation of the Central Mobile Belt, Canadian Appalachians. Journal of Geology, 96, pp. 535-547.

VAN STAAL, C.R. 1987. Tectonic setting of the Tetagouche Group in northern New Brunswick: implications for plate tectonic models of the northem Appalachians. Canadian Journal of Earth Sciences, 24, pp. 1329-1351.

WILLIAMS, H. and HATCHER, R.D. 1982. Suspect terranes and accretionary history of the Appalachian orogen. Geology, 10, pp.
$530-536$.

WILSON, J.T. 1966. Did the Atlantic close and then re-open? Nature, 211, pp. 676-681.

WINCHESTER, J.A. and FLOYD, P.A. 1976. Geochemical magma type discrimination: Application to altered and metamorphosed basic igneous rocks. Earth and Planetary Science Letters, 28, pp. 459-469.

- 1977. Geochemical discrimination of different magma series and their differentiation products using immobile elements. Chemical Geology, 20, pp. 325-343.

ZEN, E-AN. 1983. Exotic terranes in the New England Appalachians - limits, candidates, and ages: a speculative essay. In Contributions to the Geology and Geophysics of Mountain Chains. Edited by R.D. Hatcher, H. Williams, and I. Zietz. Geological Society of America, Memoir 158, pp. 55-81.

\section{APPENDIX 1: Analytical Procedures}

Penobscot Fomation (Samples 9, 56, 75)

Major and trace elements by $\mathrm{X}$-ray fluorescence at the U.S. Geological Survey Branch of Analytical Laboratories, Reston, Virginia (Samples 56 and 75). Precision: $>20$ ppm, $\pm 5 \%$; $<20$ ppm, \pm 2 ppm absolute. Analysts: R. Johnson, K. Dennen, B. Scott.

Rare earth elements, $\mathrm{Zn}$ and $\mathrm{Cr}$ by instrumental neutron activation analysis at U.S. Geological Survey, Radiochemistry Laboratory, Denver, Colorado (Samples 56 and 75). Precision: all values, $\pm 10 \%$; most $\pm 5 \%$. Analyst: L. Schwarz.

Rare earth elements on sample 9 by inductively coupled plasma/mass spectrometry at X-ray Assay Laboratories, Don Mills, Ontario. Precision: $\pm 10 \%$.

Calais Formation (Samples 1 to 8)

Major and trace elements by X-ray fluorescence at Regional XRF Centre, Saint Mary's University, Halifax, N.S. (Samples 1 to 6) and at X-ray Assay Laboratories, Don Mills, Ontario (Samples 7 and 8). Precision: Saint Mary's, $\pm 5 \%$ for major oxides, $\pm 5-10 \%$ for trace elements; X-ray Assay, $\pm 2 \%$ for major oxides, $\pm 10-20 \%$ for trace elements. Analyst: Saint Mary's, K. Cameron.

Rare earth elements by inductively coupled plasma/mass spectrometry at X-ray Assay Laboratories, Don Mills, Ontario. Precision: $\pm 10 \%$. 